\title{
PEMBUKTIAN TERBALIK TERHADAP PERAMPASAN ASET DALAM PERKARA TINDAK PIDANA PENCUCIAN UANG HASIL KEJ AHATAN NARKOTIKA
}

\author{
Andri \\ Emai : andri.banjar77@ gmail.com \\ Mahasis wa Program Magister Ilmu Hukum,Program Pascasarjana \\ Fakultas Hukum Universitas Sebelas Maret Surakarta \\ Supanto \\ Email :supanto.8787@gmail.com \\ Dosen Fakultas Hukum Universitas Sebelas Maret Surakarta
}

\begin{abstract}
This paper aims to assess the implemention of proof reversed money laundering in the case of narcotics assets is a criminal offense so seized for the stste as stipulated in law No.8 year 2010 on Prevention and eradication of money laundering and the law No.35 year 2009 on narcotics review of the Indonesian criminal justice system. This article is a normative legal research with the nature of the research is descriptive and forms of research is perspective. Approach legislation with secondary data sources such as the primary legal materials, secondary and tertiary. Techniques of data collection is done by the study documents or library materials and analyzed using the methods of reasoning deduktif.Pembuktian in court in essence is the obligation of public prosecutor to convince a judge to the defendant errors projected to provide sufficient grounds for the judge of the truth of the events proposed in the indictment. This is in accordance with Article 66 of the Criminal Procedure Code which states that the defendant is not burdened with evidence in the trial of what is charged to him, in addition to the testimony of the defendant alone is not enough to prove him guilty of committing acts against her, but must be accompanied by other evidence (vide Article 189 paragraph (4) criminal Procedure Code), in other words, the criminal Code does not recognize the process of proof imposed on Terdakwa.Konsep reversed evidence of money laundering in the prevention of narcotics cases whose assets are the proceeds of crime from the perspective of criminal procedural law, namely the first one is the trial of request handling Assets In Money Laundering by investigators by the Indonesian Supreme Court Regulation No. 01 Year 2013 on the Procedures for S ettlement Request handling Assets In Money Laundering C rime Or Other. Both the concept of proof of money laundering in the prevention of narcotics cases whose assets are the proceeds of crime from the perspective of criminal procedure is based on Article 77 of Law No. 8 of 2010 concerning the prevention and eradication of money laundering and Article 98 of Law No. 35 of 2009 on narcotics jo PP No.40 of 2013 on the implementation of Article 44 of the narcotics Act in the management of proceeds of crime, narcotics
\end{abstract}

Keywords: Inverted proof, Criminal Procedure Law, criminal acts of money laundering (Law No. 8 of 2010), Crime Narcotics (Act 35 of 2009), Asset Confiscation of proceeds of crime

\begin{abstract}
Abstrak
Tulisan ini bertujuan mengaji pelaksanaan pembuktian terbalik tindak pidana pencucian uang dalam kasus narkotika yang asetnya merupakan hasil tindak pidana sehingga diramvpas untuk negara sebagaimana yang diatur dalam undang-undang No.8 Tahun 2010 tentang Pengecahan dan Pemberantasan Tindak Pidana Pencucian serta undang-undang No.35 Tahun 2009 tentang Narkotika yang ditinjau dari hukum acara pidana Indonesia dari sistem peradilan pidana Indonesia. Tulisan ini adalah penelitian hukum normatif dengan sifat penelitian bersifat deskriptif dan bentuk penelitian yang digunakan adalah perspektif. Pendekatan perundang-undangan dengan sumber data sekunder berupa bahan hukum primair, sekunder dan tersier. Tehnik pengumpulan data dilakukan dengan cara studi dokumen atau bahan pustaka dan dianalisis dengan menggunakan metode penalaran deduktif. Pembuktian di persidangan pada pokoknya merupakan kewajiban Penuntut Umum untuk meyakinkan hakim terhadap kesalahan Terdakwa yang diproyeksikan untuk memberikan dasar-dasar yang cukup bagi hakim tentang kebenaran peristiwa yang diajukan dalam surat dakwaan. Hal ini selaras dengan Pasal 66 KUHAP yang menyebutkan bahwa
\end{abstract}


Terdakwa tidak dibebani pembuktian di persidangan terhadap apa yang didakwakan kepadanya, di samping itu keterangan terdakwa saja juga tidak cukup untuk membuktikan dirinya bersalah melakukan perbuatan yang didakwakan kepadanya, melainkan harus disertai dengan alat bukti lainnya (vide Pasal 189 ayat (4) KUHAP), dengan kata lain KUHAP tidak mengenal proses pembuktian terbalik yang dibebankan kepada Terdakwa. Konsep pembuktian terbalik tindak pidana pencucian uang dalam penanggulangan kasus Narkotika yang asetnya hasil tindak pidana dari perspektif hukum acara pidana yakni yang pertama adalah persidangan terhadap permohonan penanganan Harta Kekayaan Dalam Tindak Pidana Pencucian Uang dilakukan penyidik berdasarkan Peraturan Mahkamah Agung Republik Indonesia Nomor 01 Tahun 2013 Tentang Tata Cara Penyelesaian Permohonan Penanganan Harta Kekayaan Dalam Tindak Pidana Pencucian Uang Atau Tindak Pidana Lain. Kedua konsep pembuktian terbalik tindak pidana pencucian uang dalam penanggulangan kasus Narkotika yang as etnya hasil tindak pidana dari perspektif hukum acara pidana didasarkan Pasal 77 Undang-undang No.8 Tahun 2010 tentang Pencegahan dan pemberatasan tindak pidana pencucian uang dan Pasal 98 Undang-Undang No 35 Tahun 2009 tentang Narkotika jo PP No.40 Tahun 2013 tentang pelaksanaan UU Narkotika pada Pasal 44 pengurusan hasil tindak pidana narkotika.

Kata kunci : Pembuktian terbalik, Hukum Acara Pidana, Tindak pidana P encucian uang(UU No.8 Tahun 2010), Tindak Pidana Narkotika(UU No.35 Tahun 2009), Perampasan Aset Hasil Tindak Pidana.

\section{A. Pendahuluan}

Pembuktian adalah suatu proses kegiatan untuk membuktikan sesuatu atau menyatakan kebenaran tentang suatu peristiwa. Di dalam KUHAP kewajiban pembuktian dibebankan sepenuhnya kepada Jaksa Penuntut Umum, hal ini sesuai dengan ketentuan KUHAP Bab VI Pasal 66 dan ketentuan pembuktian yang diatur dalam KUHAP Bab XVI bagian ke empat (Pasal 183 sampai dengan Pasal 232 KUHAP), sehingga status hukum atau kedudukan asas pembuktian terbalik di dalam sistem hukum acara pidana di Indonesia (KUHAP) tidak diatur. Sesuai dengan Pasal 66 dan 183 KUHAP, maka jelaslah bahwa kedudukan asas pembuktian terbalik tidak dianut dalam sistem hukum acara pidana pada umumnya (KUHAP), melainkan yang sering diterapkan dalam proses pembuktian dalam peradilan pidana yaitu teori jalan tengah yakni gabungan dari teori berdasarkan undang-undang dan teori berdasarkan keyakinan hakim.

Konsep pembuktian terbalik terdapat dalam Pasal 77 Undang-Undang Nomor 8 Tahun 2010 Tentang Pencegahan Dan Pemberantasan Tindak Pidana Pencucian Uangserta berdasarkan Pasal 98 Undang-Undang No 35 Tahun 2009 tentang Tindak Pidana Narkotika.

Sistem pembuktian terbalik yang diatur dalam Pasal 77 tersebut merupakan implementasi dari tujuan diberlakukannya undang-undang tindak pidana pencucian yang baru sebagaimana termaktub dalam bagian penjelasan umum yang menyebutkan :
“...Dalam konsep anti pencucian uang, pelaku dan hasil tindak pidana dapat diketahui melalui penelusuran untuk selanjutnya hasil tindak pidana tersebut dirampas untuk negara atau dikembalikan kepada yang berhak. Apabila Harta Kekayaan hasil tindak pidana yang dikuasai oleh pelaku atau organisasi kejahatan dapat disita atau dirampas, dengan sendirinya dapat menurunkan tingkat kriminalitas. Untuk itu upaya pencegahan dan pemberantasan tindak pidana Pencucian Uang memerlukan landasan hukum yang kuat untuk menjamin kepastian hukum, efektivitas penegakan hukum serta penelusuran dan pengembalian Harta Kekayaan hasil tindak pidana.."

“.. Upaya yang dilakukan tersebut dirasakan belum optimal, antara lain karena peraturan perundang-undangan yang ada ternyata masih memberikan ruang timbulnya penafsiran yang berbeda-beda, adanya celah hukum, kurang tepatnya pemberian sanksi, belum dimanfaatkannya pergeseran beban pembuktian “

Sistem pembuktian terbalik dapat dipahami sebagai bagian untuk mencegah dan memberantas tindak pidana pencucian uang, mengingat dua hal penting yang dapat ditimbulkan yaitu merugikan masyarakat dan tingkat kompleksitas modus operandi yang dilakukan, sehingga sistem pembuktian terbalik sangat dibutuhkan oleh karena kejahatan ini tergolong rumit, terlebih jika dilakukan secara 
berlanjut (following up crime) yang bersumber dari kejahatan asal (predicate offense atau core crime).(Romli Atmasasmita, Harapan Masa Depan Pemberantasan Pencucian Uang. www.legalitas. org, 2007:1. Dan Yeni Garnasih, 2005 Anti Pencucian di Indonesia dan Kelemahan Dalam Implementasinya (Suatu Tinjauan Awal), www. legalitas.org di akses Kamis 15 September 2016 jam $11.30 \mathrm{Wib})$. Bahwa sebagaimana halnya Undang-undang Nomor 8 Tahun 2010 tentang Pencegahan dan Pemberantasan Tindak Pidana Pencucian Uang sebagai lex specialist dari KUHAP, Undang-undang Nomor 35 tahun 2009 tentang Narkotika juga mengatur tentang sistem pembuktian terbalik. Hal ini sebagaimana ketentuan Pasal 98 yang menyebutkan:

'Hakim berwenang meminta terdakwa membuktikan bahwa seluruh harta kekayaan dan harta benda istri, suami, anak, dan setiap orang atau korporasi bukan berasal dari hasil tindak pidana Narkotika dan Prekursor Narkotika yang dilakukan terdakwa.'

Apabila Terdakwa tidak dapat membuktikan harta kekayaan yang disita oleh penyidik merupakan harta yang diperoleh secara sah bukan dari kejahatan Narkotika, maka mengacu pada ketentuan Pasal 101 ayat (3) harta kekayaannya tersebut dapat dirampas untuk negara dalam putusan pengadilan. Di samping itu menurut penulis Terdakwa juga dapat dikenakan Pasal 137 huruf a atau $b$ aturan pasal tindak pidana pencucian uang di samping predicate crime yang telah dilakukannya.

Terdakwa dibebankan untuk membuktikan asal-usul harta kekayaan yang dimilikinya, hal ini dapat dianggap sebagai suatu penyimpangan dari asas pembuktian yang dianut oleh KUHAP disamping berubahnya paradigma dari asas praduga tak bersalah (presumption of innocent) menjadi asas praduga bersalah (presumption of guit). Melalui proses pembuktian ini dapat ditentukan seorang terdakwa untuk dibebaskan (vrijspraak), dilepaskan dari segala tuntutan hukum (onslag van alle rechtsvervolging), atau dipidana(Elwi Danil,J akarta, 2012:193) menurut penulis hal ini hanya didasarkan pada kemampuan Terdakwa dalam membuktikan asal-usul harta kekayaan yang dimilikinya. J ika Terdakwa tidak dapat membuktikannya, maka harta kekayaannya tersebut dapat dirampas untuk negara.

Mengacu pada hal tersebut maka menurut penulis terdapatperbedaan mengenai pembuktian terbalik yang diatur dalam Undang-undang
Nomor 8 Tahun 2010 tentang Pencegahandan Pemberantasan Tindak Pidana Pencucian Uang (kewajiban Terdakwa) dan Undang-Undang Nomor 35 Tahun 2009 tentang Narkotika (dapat dilaksanakan atas perintah hakim). Dalam penerapannya pada praktik penegakan hukum menurut penulis juga terdapat adanya keraguan, bahkan jarang sekali dalam proses pembuktian di sidang pengadilan diterapkan pembuktian terbalik dalam tindak pidana pencucian uang dari hasil kejahatan narkotika baik kewajiban terdakwa untuk membuktikan ataupun dengan kewenangan hakim memerintahkan terdakwa untuk membuktikan harta kekayaan atau harta benda tidak ada hubungannya atau bukan hasil tindak pidana, sehingga dalam proses pembuktian disidang pengadilan tetap kewajiban Penuntut Umum untuk membuktikan dengan mengajukan alat bukti yang sah dan meyakinkan hakim bahwa harta kekayaan dan harta benda yang disita merupakan ada hubungan atau hasil dari tindak pidana.

Hal ini dapatdilihat dalam putusan pengadilan terhadap kasus tindak pidana narkotika yang uangnya disamarkan asal-usul harta kekayaan atau harta bendanya yang merupakan tindak pidana pencucian uang diantaranya kasus pelakunya suami-istri yang melakukan tindak pidana narkotika dan pencucian uang atas nama terpidana SURJADI WIDJ AJA Alias RICKY (putusan Pengadilan Tinggi Bandung Nomor:319/ PID/SUS/2013/PT.Bdg) dan Terpidana TJ OE MEI LAN (putusan P engadilan Tinggi Bandung Nomor: 320/PID. SUS/2013/PT. BDG) yang mereka didakwa dengan Undang-undang Nomor 8 Tahun 2010 tentang Pencegahandan Pemberantasan Tindak Pidana Pencucian Uang, juga didakwa dengan Undang-Undang Nomor 35 Tahun 2009 tentang Narkotika. Sedangkan kasus tindak pidana pencucian uang yang tersendiri dimana pelaku melakukan tindak pidana pencucian uang yang diterimanya dari hasil kejahatan narkotika agar harta kekayaan atau harta benda menjadi legal seperti perkara atas nama Terdakwa RUSMALIANA als ROSA Binti J AHUDIN (P utusan Pengadilan Tinggi Pekanbaru Nomor:269/PID. SUS/2012/PTR tanggal 29 J anuari 2013) yang didakwa melakukan tindak pidana pencucian uang sebagaimana diatur dalam Undang-undang Naroktika dan Undang-undang pencegahan dan pemberantasan tindak pidana pencucian uang.

Mengenai kewenangan penyidikan, Pasal 74Undang-Undang Nomor 8 Tahun 2010 tentang Pencegahan dan Pemberantasan Tindak 
Pidana Pencucian Uang menyebutkan bahwa penyelesaian tindak pidana pencucian uang dapat dilakukan oleh penyidik tindak pidana asal, artinya apabila penyidik tindak pidana asal menemukan indikasi tindak pencucian pencucian yang didasarkan pada 2 (dua) alat bukti yang sah maka penyidik dapat menggabungkan proses penyidikan tindak pidana asal dan tindak pidana pencucian uang. Sementara itu dalam UndangUndang Nomor 35 Tahun 2009 tentang Narkotika hanya mengatur kewenangan Penyidik Kepolisian Negara Republik Indonesia dan penyidik BNN terhadap penyidikan perkara penyalahgunaan dan peredaran gelap Narkotika/P rekursor Narkotika (vide Pasal 81). Padahal selain kwalifikasi tindak pidana tersebut, dalam Pasal 137 juga diatur tentang tindak pidana pencucian uang hasil kejahatan Narkotika, namun tidak terdapat norma yang menyebutkan kewenangan untuk menyidik perkara pencucian uang hasil kejahatan Narkotika. Hanya saja pada Pasal 2 ayat (1) huruf c UndangUndang Nomor 8 Tahun 2010 tentang Pencegahan dan Pemberantasan Tindak Pidana Pencucian Uang disebutkan kejahatan Narkotika sebagai salah satu tindak pidana asal.

Sehubungan dengan itu pakar hukum Yenti Garnasih menilai bahwa penerapan Tindak Pidana Pencucian Uang dalam perkara narkotika belum efektif sebabtidak semua bandar narkotika dikenakan TPPU. Indonesia baru dinyatakan bebas dari pencucian uang dalam lingkup pendanaan terorisme oleh Financial Action Task Force (FATF) di Paris pada tanggal 24 Februari 2015. S edangkan kejahatan luar biasa lainnya yaitu narkotika, Indonesia masih tergolong rawan pencucian uang dalam skala internasional.(Yeti Garnasih, Penerapan TPPU Dalam Perkara Narkotika Belum Efektif, http://sp.beritasatu. com/home/penerapan-tppu-dalam-perkaranarkotika-belum-efektiif ,diakses, Kamis, 17 September 2015 jam $12.30 \mathrm{Wib}$ ) tentunya setiap pelaku tindak pidana Narkotika akan berusaha menyembunyikan atau menyamarkan asal-usul harta kekayaannya dengan berbagai cara agar sulit ditelusuri oleh aparat penegak hukum, sehingga dapat dengan leluasa memanfaatkan harta kekayaan tersebut baik untuk kegiatan yang sah maupun yang tidak sah. Untuk itu diperlukan aturan hukum yang baik untuk mewujudkan kepastian hukum berdasarkan pembuktian secara formil sehingga dapat terwujud tujuan hukumnya berupa keadilandan kemanfaatan hukum yang proporsional dan seimbang. Berdasarkan konsep pokok-pokok pemikiran tersebut diatas maka dalam penulisan artikel ini akan dibahas berkenaan denganpengaturan pembuktian terbalik terhadap perampasan asset dari hasil kejahatan Narkotika dalam kedua undang-undang tersebut melalui pandangan hukum pidana berupa KUHAP (hukum acara pidana Indonesia) serta apakah pengaturan tersebut telah sesuai dengan prinsip pembuktian sebagaimana dalam hukum acara pidana pada sistem peradilan pidana Indonesia.

\section{B. Metode Penelitian}

Penelitian berdasarkan norma hukum sebagai penelitian doktrinal(S etiono, Surakarta, 2005:1)Penelitian ini disebut juga yuridis normatif yang mengarahkan penelitian pada data sekunder seperti buku-buku hukum, hukum positif, norma tertulis ataupun perundangundangan yang berkaitan dengan pembahasan penelitian(S ri Mamudji, J akarta, 2005:10). Burhan Ashshofamendefinisikan metodologi doktrinal sebagai norma yang berupa asas normal, keadilan atau yang telah dipositifkan sebagai hukum perundang-undangan(Burhan Ashsofa, J akarta, 2001: 21-22). Dilihat dari sudut sifatnya, maka penelitian ini termasuk kedalam bentuk penelitian deskriptif dimaksudkan untuk memberikan data yang diteliti seteliti mungkin tentang manusia, keadaan atau gejala lainnya, dengan maksud untuk mempertegas hipotesa-hipotesa agar dapat membantu didalam memperkuat teori-terori hukum yang disajikan(Setiono, Surakarta, 2005:5). Dalam rangka memahami dan menemukan jawaban atas permasalahan-permasalahan dalam penelitian ini, maka pendekatan yang akan digunakan oleh penulis adalah pendekatan perundangundangan (statute approach), pendekatan kasus (case approach) dan pendekatan perbandingan (comparative approach)(J ohni Ibrahim, Malang,2007:300). Teknik pengumpulan data yang digunakan dalam penelitian hukum ini adalah inventarisasi data sekunder yang berupa bahan-bahan hukum yang ada. Penelitian yang berdasarkan studi pustaka atau data perpustakaan yakni "untuk mencari konsepsi-konsepsi, teoriteori, pendapatatau penemuan yang berhubungan erat dengan pokok permasalahan(Khudzaifah Dimyati, Surakarta, 2012:3). Analisis data dilakukan dengan langkah menginventarisasi peraturan yang berkaitan dan akan dibahas dan dengan memperhatikan penafsiran hukum yang dilakukan dalam asas-asas hukum yang berlaku pada ilmu hukum(Setiono, Surakarta, 2005: 2627). 
C. Hasil Penelitian dan Pembahasan

1. Pelaksanaan Pembuktian Terbalik Terhadap Perampasan Aset Dalam Perkara Tindak Pidana Pencucian Uang Yang Diperoleh Dari Kejahatan Narkotika.
Sistem pembuktian terbalik tindak pidana pencucian uang terhadap hasil tindak pidana narkoba dapat di gambarkan sebagai berikut:

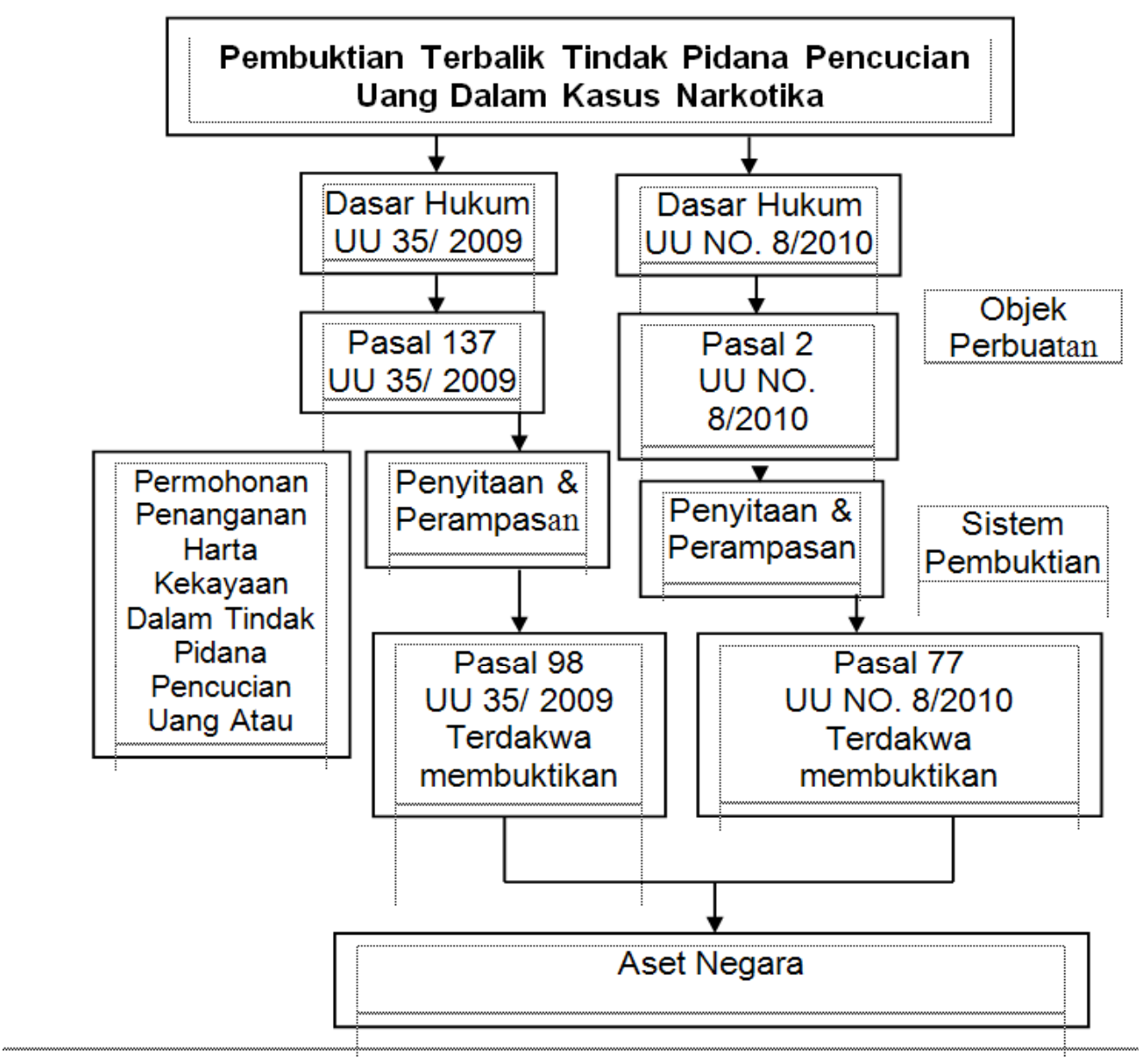

Konsep pembuktian terbalik baik berdasarkan Pasal 98 Undang-Undang No 35 Tahun 2009 tentang Tindak P idana Narkotika maupun Pasal 77 Undang-Undang Nomor 8 Tahun 2010 Tentang Pencegahan Dan Pemberantasan Tindak Pidana Pencucian Uang, pada dasarnya sama atau sebanding. Hanya saja Undang-Undang Nomor 8 Tahun 2010 Tentang Pencegahan Dan Pemberantasan Tindak Pidana Pencucian Uang memiliki sarana yang cukup lengkap seperti pengaturan mengenai PPATK dan lainnya.

Proses Penanganan Harta Kekayaan Dalam Tindak Pidana Pencucian Uang dilakukan melalui permohonan berdasarkan
Peraturan Mahkamah Agung Republik Indonesia Nomor 01 Tahun 2013 Tentang

Tata Cara Penyelesaian Permohonan Penanganan Harta Kekayaan Dalam Tindak P idana Pencucian Uang Atau Tindak Pidana Lain. Permohonan penanganan harta kekayaan diajukan oleh Penyidik dalam hal yang diduga sebagai pelaku tindak pidana tidak diternukan sebagaimana dimaksud dalam Undang-U ndang Nomor 8 Tahun 2010 tentang Pencegahan dan Pemberantasan Tindak P idana Pencucian Uang.

Rancangan Undang-undang perampasan aset terdapat 2(dua) bentuk perampasan aset yakni pertamaPerampasan In Rem adalah 
tindakan negara mengambil alih aset melalui putusan pengadilan dalam perkara perdata berdasarkan bukti-bukti yang lebih kuat bahwa aset tersebut yang diduga berasal dari tindak pidana atau digunakan untuk tindak pidana dan kedua P erampasan P idana adalah tindakan negara menuntut mengambil alih aset melalui putusan pengadilan dalam perkara pidana sebagaimana yang diatur dalam Pasal 35 ayat (1) perampasan pidana dilakukan terhadap barang yang terkait langsung dengan tindak pidana dan dijadikan sebagai barang bukti di dalam berkas perkara dan ayat (2) mengatur tata cara perampasan pidana dilakukan menurut tata cara yang diatur di dalam hukum acara pidana.

Pasal 44 Peraturan Pemerintah Republik Indonesia Nomor 40 Tahun 2013 Tentang Pelaksanaan Undang-Undang Nomor 35 Tahun 2009 Tentang Narkotika menyatakan bahwa, aset Tindak Pidana berdasarkan putusan pengadilan yang telah memperole kekuatan hukum tetapdinyatakan dirampas untuk negara. Tata cara pengurusan, pengelolaan, dan penggunaan Aset Tindak Pidana dilaksanakan sesuaidengan ketentuan peraturan perundang-undangan.

Mekanisme kordinasi antara penyidik dan penuntut umum dalam perampasan aset tindak pidana pencucian uang pada kasus narkotika terbagi kedalam 4 fase yaitu pelacakan aset, pembekuan aset, penyitaan dan perampasan. Kordinasi pelacakan dilakukan oleh BNN, Penyidik Polri, PPATK dalam hal ini penyidik melakukan pelacakan atas aset aset hasil tindak pidana narkotika melalui PPATK. Paska pelacakan maka apabila ditemukan asetnya akan dilakukan pembekuan. Dalam hal ini dilakukan kordinasi BNN, Penyidik Polri, PPATK, Bank/ instansi keuangan. Setelah dilakukan pembekuan maka dilakukan penyitaan sebagaimana Undang-Undang No 35 Tahun 2009 tentang Narkotika dan KUHAP mengatur yang boleh melakukan penyitaan adalah BNN, Penyidik Polri, Penyidik PPNS. Mekanisme terakhir adalah perampasan. Aset yang diduga tindak pidana pencucian uang kasus narkotika dilakukan penuntutan ke persidangan. Melalui pembuktian terbalik, hakim akan memeriksa harta tersebut apakah hasil tindak pidana atau bukan. Seluruh harta kekayaan atau harta benda yang merupakan hasil tindak pidana Narkotika dan Prekursor Narkotika dan tindak pidana pencucian uang dari tindak pidana Narkotika dan Prekursor Narkotika berdasarkan putusan pengadilan yang telah memperoleh kekuatan hukum tetap dirampas untuk negara.

2. Pembuktian Terbalik Dalam UndangUndang Nomor 8 Tahun 2010 Tanggal 22 Oktober 2010 Tentang Pencegahan dan Pemberantasan Tindak Pidana Pencucian Uang dan Undang-Undang Nomor 35 Tahun 2009 Tanggal 12 Oktober 2009 Tentang Narkotika Pada Sistem Peradilan Pidana Indonesia.

Pembuktian adalah suatu proses kegiatan untuk membuktikan sesuatu atau menyatakan kebenaran tentang suatu peristiwa. Di dalam KUHAP kewajiban pembuktian dibebankan sepenuhnya kepada J aksa Penuntut Umum, hal ini sesuai dengan ketentuan KUHAP Bab VI Pasal 66 dan ketentuan pembuktian yang diatur dalam KUHAP Bab XVI bagian ke empat (Pasal 183 sampai dengan Pasal 232 KUHAP), sehingga status hukum atau kedudukan asas pembuktian terbalik di dalam sistem hukum acara pidana di Indonesia (KUHAP) tidak diatur. Sesuai dengan Pasal 66 dan 183 KUHAP, maka jelaslah bahwa kedudukan asas pembuktian terbalik tidak dianut dalam sistem hukum acara pidana pada umumnya (KUHAP), melainkan yang sering diterapkan dalam proses pembuktian dalam peradilan pidana yaitu teori jalan tengah yakni gabungan dari teori berdasarkan undang-undang dan teori berdasarkan keyakinan hakim.

Sehingga sudah jelas KUHAP tidak mengatur sistem pembuktian terbalik dimana pelaku dianggap bersalah atau asas praduga bersalah(presumption of guilt), secara kongkrit perkembangan hukum pidana dewasa ini KUHAP dalam kenyataannya sudah bukan lagi suatu kodifikasi hukum atau kompilasi hukum acara pidana Indonesia tapi sebuah aturan kitab yang hanya memuat sebagian besar saja hukum acara pidana Indonesia dan faedahnya bersifat norma hukum yang mengatur secara umum(lex generalis). Sedangkan pengaturan diluar KUHAP yang salah satunya pembuktian terbalik diatur undang-undang khusus tersendiri misalnya UU Narkotika dan UU TTPU yang salah satunya mengatur pembuktian terbalik yang berada diluar kelaziman teoritis pembuktian dalam hukum 
acara pidana yang universal,Pemberantasan tindak pidana pencucian uang di Indonesia dimulai pada 1988 ketika United Nations Convention Against Illicit Traffic in Narcotic Drugs and Psychotropic Substancesdengan meratifikasiUU No. 7 Tahun 1997 tentang Pengesahan Konvensi Perserikatan Bangsa Bangsa tentang Pemberantasan Peredaran Gelap Narkotika dan Psikotropika, yang kemudian kriminalisasi dalam UndangUndang No.35 Tahun 2009 tentang Narkotika dalam hal TTPU dan pembuktian terbalik harta kekayaan hasil tindak pidana, termasuk juga dengan Konvensi Anti Korupsi 2003 yang telah diratifikasi oleh pemerintah Indonesia melalui UU No.7 tahun 2006 tentang Pengesahan United Nations Convention Against Corruption, tahun 2003, telah memuat ketentuan mengenai sistem pembalikan beban pembuktian yaitu dalam Pasal 31 ayat 8 dalam konteks proses pembekuan (freezing), perampasan(seizure) dan penyitaan(confiscation) dan pendapat ahli hukum pidana Indriyanto Seno Aji tentang pembuktian terbalik yakni : "Hanya saja dalam "certain cases"(kasus-kasus tertentu) diperkenankan penerapan dengan mekanisme yang diferensial, yaitu sistem pembalikan beban pembuktian atau dikenal dengan "R eversal of Burden P roof"(O mkering va Bewjislast) itupun tidak dilakukan secara overall, tetapi memiliki batas-batas yang seminimal mungkin tidak melakukan suatu desktruksi terhadap perlindungan dan penghargaan HakAsasi Manusia, khususnya Hak Tersangka atau Terdakwa".

Pembuktian terbalik yang dibebankan kepada tersangka atau terdakwa menimbulkan anggapan dan persepsi merupakan penyimpangan dari asas praduga tak bersalah dan terjadinya pelanggaran Hak Asasi Manusia dimana adanya proses perpindahan beban pembuktian dalam KUHAP yakni secara umum merupakan kewajiban Jaksa penuntut umum namun dibebankan kepada pelaku tindak pidana wajib untuk membuktikan asal-usul kekayaannya bukan dari tindak pidana, artinya beban pembuktian terbalik tersebut dalam penerapannya dibatasi pada tindak pidana tertentu saja dan berkenaan dengan harta kekayaan yang pembuktiannya dilakukan tahap persidangan, walaupun dalam prakteknya pembuktian kesalahan dan proses hukum di sidang pengadilan tetap kewajiban jaksa penuntut umum untuk membuktikan dengan kata lain proses pembuktian di sidang pengadilan pembuktiannya bersifat tidak murni yakni terbatas dan berimbang.

Penerapan pembuktian terbalik yang berimbang bertujuan untuk menghindari penyalahgunaan wewenang dalam proses hukum, contohnya hal ini dapat dilihat dalam undang-undang korupsi dimana penerapan pembuktian terbalik hanya diberlakukan pada delik gratifikasi suap sesuai Pasal 12B UU No.20 Tahun 2001, sedangkan tindak pidana narkotika dan tindak pidana pencucian uang untuk penerapan pembuktian terbalik berlaku pada pembuktian asal-usul harta kekayaan yang dianggap dari hasil tindak pidana sebagaimana diatur Pasal 77 UU No.8 Tahun 2010 tentang Pencegahan dan Penberantasan Tindak Pidana Pencucian Uang dan Pasal 98 Undang-Undang No. 35 Tahun 2009 tentang Narkotika.

Dikaitkan dengan penerapan pembuktian terbalik, maka hakim memiliki kewenangan yang absolut yang diberikan undang-undang khususnya Undang-Undang TTPU dengan memerintahkan terdakwa mewajibkan membuktikan seluruh harta kekayaannya bukan berasal hasil tindak pidana hal ini merupakan perintah undang-undang sehingga perlu peran aktif hakim menjalankan kewenangannya dalam pelaksanaan pembuktian terbalik dalam rangka merampas aset harta kekayaan yang berasal dari tindak pidana.

Berdasarkan keseluruhan uraian di atas maka dapat disimpulkan bahwa, terdapat dua track konsep pembuktian terbalik tindak pidana pencucian uang dalam penanggulangan kasus Narkotika dari perspektif hukum acara pidana. Yang pertama adalah persidangan terhadap permohonan penanganan Harta Kekayaan Dalam Tindak Pidana Pencucian Uang dilakukan penyidik berdasarkan Peraturan Mahkamah Agung Republik Indonesia Nomor 01 Tahun 2013 Tentang Tata Cara Penyelesaian Permohonan Penanganan Harta Kekayaan Dalam Tindak P idana Pencucian Uang Atau Tindak P idana Lain. Kedua konsep pembuktian terbalik tindak pidana pencucian uang dalam penanggulangan kasus Narkotika dari perspektif hukum acara pidana didasarkan Pasal 77 Undang-undang No.8 Tahun 2010 tentang Pencegahan dan pemberatasan 
tindak pidana pencucian uang dan Pasal 98 Undang-Undang No 35 Tahun 2009 tentang Narkotika jo PP No.40 Tahun 2013 tentang pelaksanaan UU Narkotika pada Pasal 44 pengurusan hasil tindak pidana narkotika.

\section{Kesimpulan}

Sistem pembuktian terbalik dalam tindak pidana pencucian uang hasil Narkotika masuk dalam acara pemeriksaan biasa di atur dalam KUHAP bagian ketiga Bab XVI, Sistem pembuktian merupakan kewenangan hakim menanyakan harta asal terdakwa menjadi keseluruhan pemeriksaan yang tidak dapat dipisahkan sehingga perlu peran aktif hakim dalam melaksanakan aturan undang-undang termasuk penerapan pembuktian terbalik,pengungkapan pembuktian terbalik sangat terkait dengan masa lamanya seorang terdakwa berkecimpung dalam binsis narkotika yang didasarkan pada pengakuan terdakwa dan alat bukti yang kuat dalam membuktikan kesalahan pelaku serta pengungkapanya kerjasama pihak terkait hingga menelusuri aset dari hasil tindak pidana yang selanjutnya diputus mempunyai kekuatan hukum yang tetap dirampas untuk negara sesuai hukum acara pidana yang belaku.

Maka terhadap hasil penelitian dan pembahasan dapat diambil kesimpulan secara garis besar dalam hal pembuktian terbalik TTPU dari hasil kejahatan narkotika yang asetnya dirampas untuk negara dilihat dari persfektif hukum acara pidana sebagaimana dalam gambar matrik sebagai berikut:

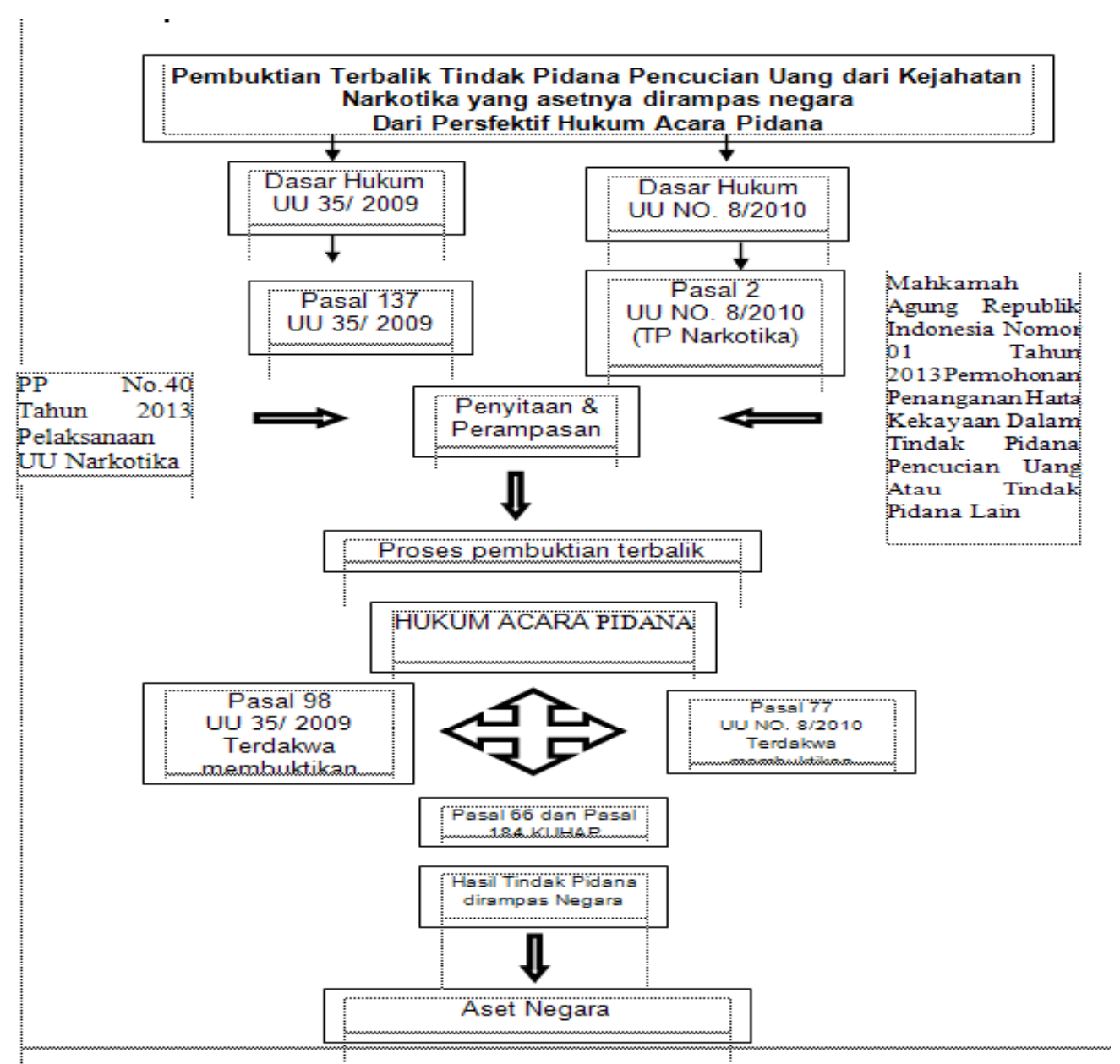




\section{E. Saran}

Pertama dalam hal pelaksaanaan pembuktian terbalik dalam suatu aturan perundang-undangan dilaksanakan dengan tegas sebagai proses penegakan hukum dalam hal ini perlu peran aktif hakim untuk menjalankan undang-undang dan agar isi suatu aturan undang-undang tidak menimbulkan penafsiran hukum yang dapat menghambat penegakan hukum. Kedua dalam pelaksanaan proses perampasan aset hasil tindak pidana maka diperlukannya landasan hukum perundang-undangan perampasan aset tindak pidana secara nasional.KetigaS inkronisasi dan harmonisasi antara Undang-Undang No 35 Tahun 2009 tentang Narkotika Undang-undang
Nomor 8 tahun 2010 tentang Pencegahan dan Pemberantasan Tindak Pidana Pencucian Uang dalam satu aturan undang-undang yang mengatur termasuk hukum acara yang mengatur ataupun langkah awal perlunya aturan peraturan pelaksana berupa peraturan pemerintah berkaitan dengan hukum acara pidana antara UU Narkotika dan UU TTPU termasuk aturan perampasan aset dari hasil tindak pidana. Keempat diperlukan lembaga khusus pemerintah dalam bidang hukum yang menangani berkenaan dengan proses pelaksanaan perampasan aset dari hasil tindak pidana baik perorangan ataupun koorporasi secara nasional.

\section{Daftar Pustaka}

\section{Buku :}

Elwi Danil . 2012.Korupsi,Konsep, Tindak Pidana dan Pemberantasannya, J akarta: Rajawali P res.

Burhan Ashsofa.2001. Metode Penelitian Hukum, J akarta : Rineka Cipta.

J ohni Ibrahim. 2007. Teori \& Metodologi Hukum Normatif, Cetakan III, J akarta:Bayumedia Publishing

Setiono.2005. Pemahaman Terhadap Metodologi Penelitian Hukum, Surakarta: Program Pascasarjana UNS

Sri Mamudji. 2005.et.al.Metode Penelitian dan Penelitian hukum, J akarta: Badan Penerbit Fakultas Hukum Universitas Indonesia.

\section{J urnal / Majalah :}

Romli Atmasasmita.2007. Harapan Masa Depan Pemberantasan Pencucian Uang,www.legalitas.org.

Yeni Garnasih.2005.Anti P encucian di Indonesia dan Kelemahan Dalam Implementasinya (Suatu Tinjauan Awal), www.legalitas.org.

Ardi Ferdian. 2014. "Sistem Pembebanan Pembuktian Terbalik Pada Tindak Pidana Korupsi",dimuat dalam arena J urnal IImu Hukum Universitas Brawijaya Malang.

Mas Ahmad Yani. 2015. "Pengendalian Sosial Kejahatan; S uatu tinjauan terhadap Masalah Penghukuman Dalam Perspektif Sosiologi".J urnal Cita HukumVol. II No 1 J akarta

\section{Peraturan Perundang-undangan :}

Undang-UndangNomor 8 Tahun 1981 Tentang KUHAP.

Undang-undang No.8 Tahun 2010 tentang Pencegahan dan pemberatasan tindak pidana pencucian uang Undang-Undang No 35 Tahun 2009 tentang Narkotika

Peraturan Mahkamah Agung Republik Indonesia Nomor 01 Tahun 2013 Tentang Tata Cara Penyelesaian Permohonan Penanganan Harta Kekayaan Dalam Tindak Pidana Pencucian Uang Atau Tindak Pidana Lain. 
PP N o.40 Tahun 2013 tentang pelaksanaan UU Narkotika pada Pasal 44 pengurusan hasil tindak pidana narkotika

\section{Putusan Pengadilan :}

Putusan Mahkamah Agung RI jam 10.00 Wib nama Terdakwa RUSMALIANA als R OSA Binti J AHUDIN (Putusan Pengadilan Tinggi Pekanbaru Nomor:269/PID.SUS/2012/PTR tanggal 29 J anuari 2013), terpidana atas nama terpidana SURJADI WIDJ AJ A Alias RICKY (putusan Pengadilan Tinggi Bandung Nomor:319/PID/S US/2013/PT.Bdg) dan Terpidana TJ OE MEI LAN (putusan Pengadilan Tinggi Bandung Nomor: 320/P ID. SUS/2013/P T. BDG)

Putusan Pengadilan Negeri J akarta Selatan Nomor:254/PIDS/2005/PN.J AK.SEL tanggal 23 J uni 2005 telah dikuatkan putusan pengadilan TinggiJ akarta Nomor 119/P ID/2005/PT.DKI tanggal 18 Agustus 2005 jo Putusan Mahkamah Agung RI Nomor 2098K/P ID/2005 tanggal 8 Maret 2006.

\section{Data Elektronik :}

Yeti Garnasih, Penerapan TP PU Dalam Perkara Narkotika Belum E fektif, http://sp. beritasatu.com/home/ penerapan-tppu-dalam-perkara-narkotika-belum-efektiif ,diakses, Kamis, 17 September 2015 jam $12.30 \mathrm{Wib}$ 